\title{
Jesus and the Demons: Portraits of the spiritual Seeing in Mark's Gospel. Origen, Bonaventure and Ignatius as hermeneutic reading key of the Gospel
}

\author{
Dempsey Rosales-Acosta \\ UNIVERSITY OF ST. THOMAS \\ HUSTON-TEXAS
}

\section{The hermeneutic Key: the Spiritual Senses}

The expression «spiritual sense» is per se a paradox. The spirit by its proper essence subsists independently from the body, and from the sensorial means that the body needs to communicate interactively with the surrounding world. In antiquity, already the platonic ideas conceive the entity of the spirit as an entity that needs to liberate itself from the body and all its functions in order to achieve its own perfection, namely to be what its nature suppose to be, free from the trap of the corporeal human body. Therefore where or how is it possible to justify such paradox?

The notion of the spiritual senses in Christianity connects itself strictly to the event of the Incarnation of Christ. Such event concretizes the notion that the invisibility of the spiritual world of God becomes a sensory experience that emphasizes the bodily senses instead of rejecting them.

The Logos through his Incarnation assumes the humanity, manifesting and revealing the mystery of God without the confusing or mixing of his two natures: divine and human. This means that the humanity of Christ is an instrument or channel of communication of the divine mystery, namely, his flesh is not the divinity itself since the human nature is not absorbed by the divine nature ${ }^{1}$. Thus the humanity assumed by the

The definition of the Council of Chalcedon (451 AD) confirms this statement: "Therefore, following the holy fathers, we all with one accord teach men to acknowledge one and the same Son, our Lord Jesus Christ, at once complete in 
Logos becomes a mean of self-communication of God with the human race through the person of the Son. Jesus makes this statement explicit when he answers to Phillip's question: «Philip said to him, «Lord, show us the Father, and it is enough for us.» Jesus said to him, «Have I been with you so long, and you still do not know me, Philip? Whoever has seen me (ho heōrakōs emé) has seen (heōraken) the Father (tón patéra). How can you say, 'Show us the Father'?» (John 14:8-9).

With the event of Christ, the anthropomorphic manifestations of Yhwh narrated in the sacred books of the first Testament achieve its summit in the incarnation of the Logos, Jesus Christ. God who is beyond any physicality becomes accessible to humanity from the corporeal receptivity of the senses. This physical experience of God does not exclude the realm of the spirit, but on the contrary assumes it. It is a total integration since the experience of faith starts at the point of the physical sensibility that awakens the spirit through the faith in Christ: «Have you come to believe because you have seen me? Blessed are those who have not seen and have believed» (John 20:29). Paul manifests the same idea according to his own experience of the kerygmatic proclamation in the apostolic era: «Thus faith comes from what is heard, and what is heard comes through the word of Christ» (Rom 10:17).

This perceptive experience that opens the human soul to the reality of faith in the man and God Jesus Christ becomes, at that moment, a spiritual sensibility of the reality. This spiritual perception includes

Godhead and complete in manhood, truly God and truly man, consisting also of a reasonable soul and body; of one substance with the Father as regards his Godhead, and at the same time of one substance with us as regards his manhood; like us in all respects, apart from sin; as regards his Godhead, begotten of the Father before the ages, but yet as regards his manhood begotten, for us men and for our salvation, of Mary the Virgin, the God-bearer; one and the same Christ, Son, Lord, Only-begotten, recognized in two natures, without confusion, without change, without division, without separation; the distinction of natures being in no way annulled by the union, but rather the characteristics of each nature being preserved and coming together to form one person and subsistence, not as parted or separated into two persons, but one and the same Son and Only-begotten God the Word, Lord Jesus Christ; even as the prophets from earliest times spoke of him, and our Lord Jesus Christ himself taught us, and the creed of the fathers has handed down to us». H. J. D. Denzinger, Enchiridion symbolorum, definitionum et declarationum de rebus fidei et morum. The Sources of Catholic Dogma (trans. Roy J. Deferrari; St. Louis 1957) n. 148. 
simultaneously the body and soul to elevate the person to the point that he or she can be considered a spiritual person. The physical and spiritual senses are interrelated to the point that the latter helps the former to perceive better the reality of the world, serving as a platform for the true mystical perception of the divine reality, as it is proposed by Corrigan: «the spiritual senses may well represent a more immediate and concrete way of seeing, a prelude to the greater immediacy of mystical seeing $»^{2}$. At this point, all the functions of the person become spiritual to the level that he/she reasons and acts through the spiritual intellect and will. Therefore the perceptions of the visible and invisible world are done through the spiritual heart, the spiritual imagination, and the spiritual senses. This phenomenon cannot be treated just only from a psychological point of view, because it goes beyond the human psychology touching the realm of the spirit. Consequently, it must be studied from a theological point of view. Then, the aesthetic experience of a believer becomes spiritual, in the sense that his or her spiritual sensibility unites the paradoxical extreme of the corporeal and spiritual means of perception in order to have a total and integrated experience of the visible and invisible world ${ }^{3}$.

Balthasar, in a very synthetic statement, establishes three loci classici from where the notions of the spiritual senses had been shaped through the Christian history. These are the writings of three illustrious figures: Origen, Bonaventure and Ignatius of Loyola ${ }^{4}$.

One of the first explicit written manifestations of the spiritual senses' conception can be found in Origen, who developed it, in his own way, on the basis of his Platonic and Biblical analysis. His influence continued through the patristic period but the written manifestations of the notion were not as systematic and evident as it can be read in Origen's writings. Through his allegorical application of exegesis, Origen perceived the spiritual meaning of the text that is already rooted in its literal sense. In this manner he constructed his notion of spiritual aesthetics taking in consideration some pericopes like the text of Hebrews 5:14 «But solid

2 K. Corrigan, Evagrius and Gregory: Mind, Soul and Body in the 4th Century (Farham, UK: Ashgate, 2009) 128.

3 Cf. H. U. von Balthasar, The Glory of the Lord. A theological Aesthetics (New York 1982) I, 366-367.

4 H. U. von Balthasar, The Glory..., 367-368.372.373. 
food is for the mature, for those whose faculties (perceptions/senses: tá aisthētēria) are trained by practice (gegumnasména) to discern good and evil» $\aleph^{5}$. At his meditation and study of the Scripture, Origen establishes:

"Anyone who looks into this subject more deeply will say that there is, as the scripture calls it, a certain divine sense which only the man who is blessed finds on this earth. Thus Solomon says: 'Thou shalt find a divine sense' there are many forms of this sense: sight which can see things superior to corporeal beings, the cherubim or seraphim being obvious instances, and a hearing which can receive impressions of sounds that have no objective existence in the air, and a taste which feeds on living bread that has come down from heaven and gives life to the world. So also there is a sense of smell which smells spiritual things, as Paul speaks of 'a sweet savour of Christ unto God', and a sense of touch in accordance with which John says that he has handled with his hands of the Word of life. The blessed prophets found this divine sense, and their vision and hearing were spiritual; in a similar way they tasted and smelt, so to speak, with a sense which was not sensible. And they touched the Word by faith so that an emanation came from him to them which healed them ${ }^{6}$.

Therefore there are two sorts of senses: one kind is mortal, corporeal, and corruptible which is proper of the bodily human condition; the other is immortal and spiritual since it forms part of the spiritual nature of the human soul. These two sorts of senses are connected, but the physicality of the corporeal sensations does not allow the interior person to awaken the spiritual senses. Balthasar highlights a fundamental truth about the manner of interpreting Origen's notion of the spiritual senses. The reader must not make a rationalistic approach of it because the sacred text of the Scriptures refers to the divine revelation and manifestations of God in the creation and human history, but on the other hand it is not just only a mystical reading or interpretation of this phenomenon completely disconnected from the intellectual aspect. Subsequently, it needs a balance approach and understanding of the notion of the five senses from a theological dimension that allows to

5 The text of Prov 2:5 and diverse passages of Song of Songs, among others, are also used by Origen because of their terminological connection with the notion of aesthetics (perception). Cf. H. U. von Balthasar, The Glory..., 368; K. Rahner, "Le début d'une doctrine des cinq sens spirituels chez Origène», Revue diascétique et de mystique, 13 (1932) 113-145.

6 Origen, C. Cels. I:48 (Chadwick, 44). 
perceive the notions of the divine revelation manifested to a human receptor capable to experience through a physical sensibility the divine manifestations that can awaken the spiritual sensibility. This sort of perception makes every person ontologically capable to elevate oneself to the point of experiencing the divine dimension of the Spirit.

"Accordingly, the five individual sensory senses are but the fall and scattering into the material of an original and richly abundant capacity to perceive God and divine things. According to Origen, these divine things can never be reduced to a mystical unity without modes, but, rather, they possess fullness and a glory that far transcend the lower fullness and glory, of which material multiplicity is only a distant reflection and likeness» ${ }^{7}$.

The notion of the spiritual sensibility or senses of the soul continues to be alive through the middle ages, even in the writings of the Syrian monks of the fifth and sixth century, among which is worth mentioning John of Apamea who states in his second Dialogue with Thomasios the need of purification from the corporeal or terrestrial concerns in order to see the invisible realities through the superior senses of the soul. The Syrian Monk speaks explicitly of the analogy between the bodily senses and the senses of the soul that makes possible for a corporeal person to perceive the invisible realities ${ }^{8}$. This notion survived in the Christian Western Tradition, appearing in a more systematic manner with Bonaventure in his Itinerarium mentis in Deum ${ }^{9}$. For Bonaventure the spiritual senses are «the acts of the human intellect and will as they grasp God in contemplation - acts which have been restored (refecti), facilitated (expediti) and brought to perfection (perfecti) by the triple infused habitus of the "virtues", the "gifts of the Holy Spirit" and the "beatitudes" ${ }^{10}$. Reading these notions of Bonaventure, one can perceive that the division between the physical and spiritual senses is so subtle that involves the notions of virtues, intellect, will, and infused gifts. This indicates a complete and integral anthropologic notion, where every person in his/her total and integral ontological being has the capacity

\footnotetext{
H. U. von Balthasar, The Glory..., 369.

Cf. Jean D’Apamée, Dialogue 2,15-16 (SC 311: 59-61).

Cf. H. U. von Balthasar, The Glor... y, 371-373.

H.U. von Balthasar, The Glory..., 372.
} 
of a sensory and spiritual experience of the Word of God in this divine economy ${ }^{11}$.

In the sixteenth century, Ignatius of Loyola in his Exercitia spiritualia ${ }^{12}$ revives the notions of the sensory experience in the field of spirituality. The total person must use the sensory capacities to revive emotions and experiences that go beyond the corporeal sensations helping the retreatant to enter in the spiritual experience of the faith in Christ's mystery. It is crucial, in this kind of exercises, to do the composition of place. The first prelude of the first exercise, Ignatius sets the principle to start a spiritual path that does not deny the humanity or corporeity. That is why the First Prelude is a composition of the situation, as if the person would see the place as forming part of it. In this way the retreatant becomes part of the biblical text or meditation experiencing it in the totality of his/her being. At this regard Ignatius affirms:

«Here it is to be noted that, in a visible contemplation or meditation -as, for instance, when one contemplates Christ our Lord, Who is visible- the composition will be to see with the sight of the imagination the corporeal place where the thing is found which I want to contemplate. I say the corporeal place, as for instance, a Temple or Mountain where Jesus Christ or Our Lady is found, according to what I want to contemplate. In an invisible contemplation or meditation -as here on the Sins- the composition will be to see with the sight of the imagination and consider that my soul is imprisoned in this corruptible body, and all the compound in this valley, as exiled among brute beasts: I say all the compound of soul and body» ${ }^{13}$.

Ignatius did perceive in the use of corporeal senses an intrinsic interconnection with the soul, to the point that their use is needed to have the spiritual experience. During the first week, the fifth exercise consists in the meditation of Hell, and the way how one can experience it is through the use of the senses in order to feel personally its reality. Having the understanding of its ugliness which stands in a sharp contrast with the wholeness of the divine economy in Christ, the retreatant will have the will to do everything that it takes to avoid it. The two preludes

\footnotetext{
11 Cf. H. U. von Balthasar, The Glor... y, 372-373.

12 The First Edition of the Exercitia spiritualia was done by Antonio Bladio in Rome, 1548.

13 Ignatius of Loyola, Spiritual Exercises (trans. Elder Mullan; New York 1914) 31.
} 
to this step state the composition of place by the use of all the corporeal senses with the help of the imagination:

«First Prelude. The first Prelude is the composition, which is here to see with the sight of the imagination the length, breadth and depth of Hell. Second Prelude. The second, to ask for what I want: it will be here to ask for interior sense of the pain which the damned suffer, in order that, if, through my faults, I should forget the love of the Eternal Lord, at least the fear of the pains may help me not to come into $\sin »^{14}$.

Then Ignatius states an illustrative point for the use of every single physical sense that must be helped by the intellect and the imagination, which makes more effective the total experience that involves the body, intellect, and spirit:

«First Point. The first Point will be to see with the sight of the imagination the great fires, and the souls as in bodies of fire. Second Point. The second, to hear with the ears wailings, howlings, cries, blasphemies against Christ our Lord and against all His Saints. Third Point. The third, to smell with the smell smoke, sulphur, dregs and putrid things. Fourth Point. The fourth, to taste with the taste bitter things, like tears, sadness and the worm of conscience. Fifth Point. The fifth, to touch with the touch; that is to say, how the fires touch and burn the souls».

This methodology is applied to every step of the exercise, starting systematically with the composition of the place or the life setting of the mystery that supposes to be meditated on. As for instance, during the second week the retreatant must meditate the mystery of the nativity, but as a prelude to it, the person must do the composition of the setting in order to experience the mystery in a personal and intimate manner.

«Second Prelude. The second, a composition, seeing the place. It will be here to see with the sight of the imagination the road from Nazareth to Bethlehem; considering the length and the breadth, and whether such road is level or through valleys or over hills; likewise looking at the place or cave of the Nativity, how large, how small, how low, how high, and how it was prepared... First Point. The first Point is to see the persons; that is, to see Our Lady and Joseph and the maid, and, after His Birth, the Child Jesus, (I) making myself a poor creature and a wretch of an unworthy slave, looking at them and serving them in

14 Ignatius of Loyola, Spiritual Exercises, 36. 
their needs, with all possible respect and reverence, as if I found myself present; and then to reflect on myself in order to draw some profit» ${ }^{15}$.

In this kind of exercise the retreatant must attune to the situation selected, concentrating through his/her mental strength in the object of meditation which is the mystery of Christ, but in doing so the person includes the sensory dimension that stimulates the spiritual sensibility, involving the person to a new dimension where God will communicate Himself directly to a retreatant through a spiritual experience ${ }^{16}$.

The conception of the senses of the soul states the analogy existing between the corporal senses and their respective spiritual counterparts that match up the sensory organs. As physical beings, humans have organs of sight, touch, smell, taste, and hearing which register impressions and experiences of the physical world. Analogically, the spiritual senses allow the person to experience the divine or supernatural realities immersed in the existential chain of events, consenting a person to have a generic divine sense (theias aisthéseos) of the presence and action of $\operatorname{God}^{17}$.

Taking in consideration this line of thought, it is needed to point out that the author of Mark's Gospel did not have in mind the notion of the five spiritual senses as it was developed by Origen and the tradition after him, but the texts taken in consideration show that the author knew a distinction between the physical and spiritual seeing, which makes possible to affirm that the intuition of the perception of two realities, the physical and supernatural, subsists interconnected in Mark's narrative, not expressed on the words of a systematic theological treatise but according to the language proper of a kerygmatic genre of the Gospel which narrates the deed and teachings of Christ.

Hence, applying the notion of the spiritual senses that helps the reader to discover different levels of meaning in the Scripture, it is possible to observe that the portraits of seeing in Jesus and the Demons induce the reader to conclude that their way of perceiving the realities or events in the narrative does not stop in the physical phenomenon, but it catches the divine immersed and hidden in the circumstantiality. So the

\footnotetext{
Ignatius of Loyola, Spiritual Exercises, 45.

16 Cf. H. U. von Balthasar, The Glor... y, 373-376.

17 Cf. P. C. Miller, Dreams in Late Antiquity: Studies in the Imagination of a Culture (Princeton 1994) 94. Also see Origen, C. Cels. I:48 (Chadwick, 43-46).
} 
manner in which Jesus sees is according to the physical and spiritual eyes concurrently. The sensory organ subsists in complete harmony with the divine nature of his soul allowing him to perceive every physical reality at a spiritual level simultaneously, making him capable to comprehend and scrutinize the total dimension of a person. Therefore, the markan portrayal of Jesus corresponds to the seeing of God: total, penetrating, personal, and effective.

The demons, on the other hand being supernatural entities, are capable to perceive the realities appertaining to their realm, but in the moment that they possess a person, the demoniac's sensory organ of sight synchronizes with the analogous spiritual sense to identify and recognize instantly the supernatural identity of Christ.

\section{Methodological path}

The methodology applied to the texts is the synchronic approach of the narrative and semantic analysis. These methodological approaches possess as a hermeneutical ground the notions of the spiritual senses, especially the spiritual seeing. Taking in consideration fundamentally the Greek canonical text in its final form, the reader can examine it, using the linguistic criteria, the semantic level of the verbs of visual perception in accordance with the context, subjects (characters) and objects of perception, emphasizing the common semantic level that is intended by the author in line with the internal evidence of Mark's narrative. For this purpose it is indispensable to start with determining the basic or standard definitions connoted in the terminology used by the author, to pass then to two specific portraits of seeing that show an unambiguous metaphysical notion of seeing, as it is in the case of Jesus and the demons.

\subsection{Mark's vocabulary}

In English the most common verb for visual perception is to see, but it is not the only one. There is a spectrum of terms employed to express different nuances and levels of seeing according to specific circumstances that normally are in use in a daily colloquial communication, like to observe, to watch, to look at, to examine, to catch sight of something, to set eyes on somebody, etc. The same phenomenon can serve as an analogy to the Greek koiné where one can find a rich spectrum of vocabulary operated to identify different semantic levels of visual perception. 
Among these, three verbs are quite prevalent in Mark's Gospel: Horáō, Blépō and Theōréō.

Horáo is a transitive verb that implies the physical sense of perception which is "to see, to perceive, to catch sight of» (Matt 24:30); «to go to see, or visit» (Heb 13:23), or to experience and to witness something. It is the basic action of seeing with the physical eyes but in addition entails the act of seeing with the mind, to perceive, and to know ${ }^{18}$. As an intransitive verb, it has the nuance of looking at someone (John 19:37), but predominantly one could apply it in warnings and instructions like «look out for, watch out, be on guard against», e. g. Matt 16:6; 18:10;27:419.

Noteworthy it is the second aorist of horáo: eiden which has the meaning of a perception by sight (Matt 2:2), to become aware of, to feel (Matt 27:54), as well as to take note by observation, to consider, to pay attention to, and to look at (Rom 11:22). Mark uses eiden five times and exclusively to describe Jesus' action of seeing. At this point His seeing cannot indicate a mere physical observation.

Horáo remains as the most common verb for seeing used in the New Testament. It appears a total of 350 times in the Gospels, Acts and Revelations. In Mark, horáo emerges a total of 59 times including its derivatives.

Blépo also has the basic meaning of to see, to look at. It denotes the sense of being able to see as distinct from blindness (Matt 12:22; 15:31; Mark 8:23; Luke 7:21). Blépo, connoting the idea of someone who sees and discerns with the bodily eye, indicates additionally the following nuances: to be possessed of sight, to have the power to see, to turn the eyes to anything (to look at, to look upon, to gaze at), to perceive by the senses, to feel, to discover by use, and to know by experience. It is also implied in the verb the meaning of comprehension and intellectual perception of ethical behavior ${ }^{20}$.

18 Cf. W. Bauer, W.F. Arndt, F.W. Gingrich and F.W. Danker, Greek-English Lexicon of the New Testament (Chicago ${ }^{2}$ 1979) 577.

19 Cf. W. Michaelis, «ópów», en G. Kittel (dir.), Theogical Dictionary of the New Testament (Eerdmans, Grand Rapids 1970) V, 340-342.

20 Cf. Moulton-Milligan, Vocabulary of the greek New Testament, « $\beta \lambda \dot{\varepsilon} \pi \omega », 113$;

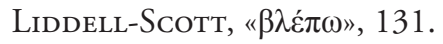


Metaphorically, the verb signifies to see with the mind's eye, to have the power of understanding, to discern mentally, to observe, to perceive and to discover until the point that can imply a feeling, to turn the thoughts or direct the mind to a thing, to consider, to look at, to weigh carefully, to examine, to look deeply into, to see through, and to become aware of the essence ${ }^{21}$. In relation to the mental functions, the verb implies directing one's attention to take notice of something or somebody, to regard or consider (1 Cor 1:26), to discover, to find, to become aware of (Rom 7:23). Additionally to these notions, it can indicate to take warning, e.g.: "watch, beware, be on guard or take heed" in Mark 13:9 (Blépete).

Mark prefers to use Horáo rather than Blépō in order to speak more explicitly of Jesus' seeing, but nevertheless Blépō and its compound forms have a total of 32 occurrences in Mark's Gospel, from which 9 appearances refer to the action of Jesus' seeing, i.e.: Mark 3:5.34; 5:32; 6:41; 7:34; 10:21.23.27; 11:11.

Theōréo has the connotation of viewing mentally or spiritually something in order to consider it. This notion indicates a physical perception that does not stop in the superficiality of the circumstantial events or persons but it signifies a deeper level of insight. Therefore theorréo other than having the basic meaning of seeing as being a spectator, to look at, to observe, to perceive with the physical eyes, also has the nuance of the perception by the mind or spirit, signifying the one who can perceive the true nature of the gods as it is already established in antiquity (Sallustius: 4.4,24), or the sublime connotation of the spiritual perception of the one sent by God. It is a seeing possible only to the one who believes, e.g., John 14:17.19; 17:2422.

Theōréo has a modest presence in Mark's Gospel, appearing only 7 times in it. It is worth mentioning the subjects of this verb in the markan narrative: Jesus appears twice in Mark 5:38; 12:41; the Demons once in Mark 3:11; the Crowd seeing the demoniac who had been cured emerges in Mark 5:15, and the Women who appear, as the predominant subject of the verb, three times in Mark 15:40.47; 16:4.

21 Cf. W. Bauer, W.F. Arndt, F.W. Gingrich and F.W. Danker, Greek-English Lexicon..., 143-144.

22 Cf. W. Bauer, W.F. Arndt, F.W. Gingrich and F.W. Danker, Greek-English Lexicon..., 360. 
Now it is fundamental to indicate that the search of a word in a specialized dictionary does not suffice the discovery process of the true meaning of a sentence according to the intention of the author who needed to discern about the choice of words to apply in a specific passage. A simple example of the modern life can illustrate this point of view regarding the biblical text. A young man who wants to learn English comes to the US, and while he is walking on the street, hears some other youngsters saying "what a cool car!». Immediately he picks his dictionary up and search for the word "cool», finding out the following definition: «moderately cold; neither warm nor cold, fresh, e.g. a rather cool evening, etc.» The problem emerges when a native English speaker understands truly the nuance of the colloquialism and realizes that the dictionary's definition does not equate with the intention and meaning of the teenagers. Hence the key element to understand the true meaning of that term or expression is the context and the circumstance in which it was pronounced. For this reason, the study of the biblical context in which every term appears, helps the reader to determine the nuances and the proper significance of the message as it was intended to be. Through this hermeneutic process, the reader uncovers the true meaning that the author had in mind when he was writing the text to a particular community of faith.

With this notion in mind, the reader must interpret Mark's Gospel not as a mathematical or systematic tractate of the verbs of visual perception where a clear distinction of them is easy to grasp in accordance with the dictionary, but precisely because of this multifaceted aspect of the Gospel, the natural desire of discovering stimulates the exegesis that must be done by the reader in order to detect other semantic levels of the markan narrative that escape, most of the time, to the superficial reading.

\section{JeSUS' SEEING}

The first active verb used by the author of Mark to describe Jesus' action in his narrative is the aorist form of the verb horáo: eiden, according to the Greek version of the Nestle-Aland $27^{\text {th }}$ ed. The first active vision of Jesus is located in the context of his Baptism when $\mathrm{He}$ saw (eiden) the heavens torn open and the Spirit descending upon him like a dove (Mark 1:10). 
Jesus appears as the explicit subject of the verb eiden. The object of his vision is dual: a) the heavens torn open (schizoménous toús ouranoùs $\left.1: 10^{a}\right)$ and $\left.b\right)$ the Spirit descending upon him like a dove $\left(1: 10^{b}\right)$. This means that the first eyesight of Jesus is marked by the vision of a non terrestrial reality. The beginning of his public ministry starts with the exclusive divine manifestation that reveals the Lord's point of interest: to look up to heaven, his Father's place, and see the Holy Spirit coming down to his own reality, namely, the one that implies to be human. Thus the first seeing of Jesus is meta-physical ${ }^{23}$ in the sense that his visual perception goes beyond or behind the physical reality that is commonly seeing by the bodily sense of sight. The meta-physical seeing trespasses the barrier of the corporeal limitations in order to see a spiritual reality that is not obvious to the naked corporeal eye, but is typical of Jesus' seeing. At the same time his visual experience is exclusive because the text of Mark 1:9-11 indicates that only Jesus was capable of seeing this dual celestial reality; the context does not indicate that other person could perceive the celestial phenomenon.

The synoptic reading of this episode highlights the distinctiveness of Jesus' seeing in Mark. A parallel analysis reveals that Matthew 3:16 indicates that the opening of the heavens is not related to Jesus' seeing, just only the Spirit of God like a dove descending on him. Matthew specifies that is the Spirit of God (tó pneüma toū Theoū), while Mark mentions only the Spirit (tó pneüma). The heavenly voice accompanying the celestial vision in Mark addresses exclusively to Jesus (Mark 1:11), unlike in Matthew where the voice speaks to others, indicating an implicit audience (Matt 3:17). The striking difference can be noticed in Luke 3:22, where the author does not make any reference to Jesus' seeing. Extending the comparison to John 1:32-34, the reader realizes that the one who sees the Spirit is John the Baptist, meanwhile Jesus is passive in the scene. The results of this brief synoptic readings and the

23 The expression «meta-physical seeing» derives from the literal etymological combination of two Greek terms: metá, a preposition that has, among many other renditions, the significance of «beyond, upon, after, behind», frequent connotation in the Homeric style, and the substantive physis which signifies «nature, natural endowment or condition", implying the naturally regulated order of things of the world that can be seen, this means the physical reality that is commonly perceived by the natural senses of perception. Cf. W. Bauer, W.F. Arndt, F.W. Gingrich and F.W. Danker, Greek-English Lexicon... , 508. 869-870. 
comparison with John, points out the special treatment of Jesus' seeing according to the theological intention of Mark.

The Old Testament has the notion of «heaven" as the abode of God (Tobit 5:16; Ps 80:14; 123:1; Eccl 5:2; Lam 3:41), as a closed place that only Yhwh can open for an extraordinary intervention or involvement with his people (2 Kgs 7:2.19; Exod 9:23; Ps 78:24; Isa 63:19); also it can entail the conception of a vision which reaches beyond the earthly dimension (Ezek 1:1). Heaven is the permanent residence of Yhwh from where he looks down and listens to the cry of his people (Deut 26:15; Ps 80:14; Isa 63:15); so the fact of seeing the heavens being rent apart (schizoménous) has a deep spiritual implication, since this aperture indicates a great intervention of Yhwh that builds a new communication between the divine and the human reality.

The verb used by Mark to qualify the "heavens» is the passive participle schizoménous of the verb schizo which means to part, to divide, to separate. This term is employed only once more in Mark's Gospel to describe the rending (eschisthē) of the Temple's veil in the context of Jesus' death (Mark 15:38), establishing a symbolic cosmic inclusio between the Baptism (1:10) and the Death of Jesus ${ }^{24}$. The term connotes a radical and new situation as it is understood by Juel: "what is opened may be closed; what is torn apart cannot easily return to its former state ${ }^{25}$. The abyss between Heaven and Earth is surpassed by the Trinitarian love of Father and Son, creating now a new communication where the humanity is assumed by the divinity. This new interaction changes completely the way humanity relates to God, and vice versa.

The descending of the Spirit makes a graphic contrast with the ascending of Jesus from the water. The narrative qualifies adjectivally the Spirit «as a dove» (hōs peristerán), a symbolic way to describe a supernatural reality that per se is without form and body, or adverbially,

24 Cf. S. Motyer, «The Rending of the Veil; A Markan Pentecost?», in New Testament Studies 33 (1987) 155-157; H. JaCKson, "The Death of Jesus in Mark and the Miracle from the Cross", in New Testament Studies 33 (1987) 22-24; D. Ulansey, "The Heavenly veil torn: Mark's Cosmic Inclusio», in Biblica 110/1 (1991) 123-124.

25 D. JuEL, A Master of Surprise: Mark Interpreted (Minneapolis 1994) 33. 
the action of descending is dove-like ${ }^{26}$. The notion of a "dove» can have multiple interpretations; it has been considered the symbol of all kinds of virtues, particularly by cause of its gentleness, innocence, and goodness that inspired this position ${ }^{27}$. But according to the Old Testament tradition, the rabbinic interpretation gives to the reader a conception that is closer to the biblical mindset manifested in Mark. Rashi commenting on Gen 1:2 affirms: "The Spirit of God was moving: the Throne of Glory was standing in the air and moving on the face of the waters by the Spirit of the mouth of the Holy One, blessed be he, and by his Word like a dove that broods on the nest» ${ }^{28}$. In the Midrash Rabbah, Rabbi Simeon ben Zoma expresses regarding the same text of Genesis the following idea: «For it is not written here, and the Spirit of God blew, but hovered, like a bird flying and flapping with its wings ${ }^{29}$. The connection is strong with the Gospel since the Spirit of God is portrayed as a bird or dove, and it is framed in a context of creation hovering upon the waters. These elements illuminate the notion of Mark indicating in the Baptism a new creation in Christ where the Trinitarian perception is explicit and exclusive of Jesus. The celestial voice in Mark 1:11 re-affirms the relationship of love between Father and Son in the new state that assumes the human condition.

The passages of the calling of the first disciples demonstrate the special seeing of Jesus, which manifests the manner how God sees. In the context of vocation, Jesus' seeing is the first step in his method of choosing the prospective disciples. Mark indicates Jesus' seeing with the aorist eiden: «he saw» in three significant passages ${ }^{30}$ :

- Mark 1:16: "And as He was going along by the Sea of Galilee, He saw (eiden) Simon and Andrew, the brother of Simon, casting a net in the sea; for they were fishermen".

26 Cf. R. T. France, "The Gospel of Mark. A commentary on the Greek Text», in New International Greek Testament Commentary (Grand Rapids, MI /Cambridge, UK 2002) 78.

27 Cf. W. Hendriksen, «The Gospel of Mark» (Grand Rapids 1975) 43-44.

28 I. Abrahams, «Studies in Pharisaism and the Gospels» (New York 1967) 49.

29 H. Freedman - M. Simon, eds., "Midrash Rabbah, Genesis» (London 1961) 18.

30 The passages are quotations from the New American Standard Bible (1977). 
- Mark 1:19: «And going on a little farther, He saw (eiden) James the son of Zebedee, and John his brother, who were also in the boat mending the nets».

- Mark 2:14: "And as He passed by, He saw (eiden) Levi the son of Alphaeus sitting in the tax office, and He said to him, "Follow Me!" And he rose and followed Him».

These three episodes present six common essential characteristics:

- Jesus is presented on the move: he is walking close by or along the sea-shore: $1: 16.19 ; 2: 13.14$. The markan portrait of Jesus is dynamic and active ${ }^{31}$.

- The initiative comes from Jesus, not from the persons who have been seen. The first main action is expressed with the aorist indicative $e i-$ den: «he saw». This particular verbal aspect indicates a punctual and unique action of perception in time ${ }^{32}$.

- The direct object of the verb eiden is the person of the disciples. What Jesus sees is the individual identified in the narrative by his personal name. The first four disciples are mentioned in pairs of brothers, they are being called to be part of a different kind of vital kinship, so as soon as they answered God's call, their brotherhood is transformed into a brotherhood of love where Jesus is the bond of this new community of faith ${ }^{33}$. The Greek text is precise in putting the personal name first followed by the brotherly qualification: "Simon and Andrew, the brother of Simon» (1:16), "James the son of Zebedee, and John his brother» (1:19). In the case of Levi, the reader observes the same pattern: Jesus sees the person then the narrative states the familiar qualification: "Levi the son of Alphaeus» (2:14). Jesus' seeing is personal and individual. The text does not say what specific uniqueness he saw in these prospective disciples, but it must be something that escapes to an exterior physical seeing. The Sight of

31 Cf. J. Palachuvattil, «He Saw». The Significance of Jesus» seeing denoted by the verb eiden in the Gospel of Mark (Roma 2002) 93.

32 Cf. M. Guerra-Gómez, El idioma del Nuevo Testamento. Gramática, estilística y diccionario estadístico del griego bíblico (Burgos 1995) 288.

33 Cf. J. Donaldson, «Called to Follow: A Twofold Experience of Discipleship in Mark», in Biblical Theology Bulletin 5 (1975) 67-77; K. Sтоск, Marco. «Commento contestuale al secondo Vangelo» (Roma 2003) 37-38. 
God goes beyond the conventionalities of culture and appearances, that is why Jesus can recognize, by way of his scrutinizing sight, the great potential of what they can be.

- The context of the seeing is the daily job activities of the chosen persons: the fishermen were casting a net in the sea or mending them, and the tax collector was sitting in his customs post. This additional detail continues to demonstrate the divine initiative that reaches the individual circumstances of the disciples.

- The calling from Jesus is direct and simple: «Follow Me and I will make you become fishers of men» $(1: 17)$, «He called them» $(1: 20)$, and He said to Levi «Follow Me!» (2:14). The calling comes after the seeing as a consequence of Jesus' visual perception.

- The reaction to Jesus' calling is positive: leaving everything they were doing, went after him. The action of following Jesus is illustrated with a verb in aorist denoting a punctual, complete, and unconditional action: followed Him (èkoloúthèsan autō 1:18), went away (apélthon) to follow Him (1:20), followed Him (èkoloúthesēn autō 2:14).

The brief narrative analysis of the three passages indicates that Jesus' seeing is the first step in the process of vocation. The divine seeing is meta-physical, namely spiritual since Jesus can perceive the totality of the person, breaking through the barriers of the superficiality imposed by the circumstances and culture. Therefore, it is not a casual look to somebody, or just a simple glance of people doing their jobs. Jesus' seeing is personal, attentive, penetrating, and selective.

The account of Mark 10:17-22 presents a context of calling (vocatio) with a negative outcome that displays a sharp contrast with the result of the calling of the first five disciples. The pericope talks about a rich man, who is very pious and faithful to the Mosaic Law. One of the most remarkable and distinctive feature of this narration can be found in the way in which Jesus looked at the man in Mark 10:21-22. The markan author utilizes the active participle aorist of the verb emblépo (emblépsas), which means to look at something or somebody deeply. It is to see everything plainly or to have a clear view of everything; also it means figuratively to look at somebody with penetrating eyes in a spiritual sense $e^{34}$. The participle

34 Cf. W. Bauer, W.F. Arndt, F.W. Gingrich and F.W. Danker, Greek-English Lexicon..., 254. 
indicates a verbal aspect of the action of seeing deeply for an extended period of time. It is not just a simple gaze in a punctual singular moment. Jesus was looking intensely into the man's soul and heart to the point that his particular and personal seeing leads to love: «And looking at him, Jesus felt a love for him» (10:21). It is precisely by cause of his incessant and profound seeing that Jesus' love of him has self presented and manifested at that moment in the unique gift of the calling to the chosen one; but the call required something else that the Lord knew thanks to his scrutinizing eyes: the wealthy man needed to put God in first place. The Lord with one statement touched the radical failure in the seemingly perfect spiritual life of this man, whose center was not completely in Yhwh. The answer to Jesus' invitation is graphic and vivid in the markan narrative: "But at these words his face fell, and he went away grieved, for he was one who owned much property» (10:22). The wealthy man did not say anything; his reaction is clearly a negative response to Jesus. The action of moving away from the Lord is accompanied with the deepest feeling of sadness, which means lack of peace and freedom. Jesus' invitation demands the perfection and radical self-giving of the chosen person, in fact Matthew 19:21 makes unequivocal this invitation in terms of perfection that is implicit in Mark: «if you wish to be perfect, go, sell...»" The pericope demonstrates that Jesus' seeing turns out to be the first step that makes his love explicit, motivating the manifestation of it in his call (vocatio). The conditional requirement of the calling indicates Jesus' spiritual seeing because albeit he admires the sincerity and integrity of someone who carefully follows the Law, also he can see concurrently what is lacking in the person. This capacity of perception goes beyond the human faculty of observation. It is the seeing of God to whom nothing can escape even the inner corners of the human soul.

The pericope of Mark 2:1-5 displays a context of healing. The important characters in this narration are four anonymous men who knowing the Lord's proximity, found the house where he was. Then being conscious of the incapacity of the cripple man to get close to Jesus, they made the effort to carry him, and despite the obstacle of the crowd, they found an original way to place the crippled before Jesus. They did

35 Cf. W. Grundmann, «Das Evangelium nach Markus», in Theologischer Handkommentar zum Neuen Testament 2. (Berlin 1977) 283; J. Donahue, D. Harrington, The Gospel of Mark (Collegeville, MN 2007) 303. 
not give up until they brought the one in need close to Lord. At this moment Jesus saw the men's faith as only God can see what is hidden from the corporeal eye. The text never says that Jesus' sees the faith of the paralytic, the only object of Jesus' seeing is "their faith», i.e. the faith of the four litter-bearers that put into motion the deed of divine healing. The verb employed is horáo in participle aorist: idon which means that is a punctual action that is not prolonged in time but it is relative in the temporal sequence indicating a logical succession of actions that culminates with the physical and spiritual healing ${ }^{36}$. Therefore after Jesus' seeing the nameless men putting the paralytic in front of him, comes as a consequence "the healing of body and soul conjointly" (Clement of Alexandria: 1.4) ${ }^{37}$. The explicit object of Jesus' seeing is the "faith» (pistis) of the anonymous bearers which can be demonstrated with actions, but in this particular case is not just only the outward manifestations of the invisible faith put in evidence in the creative way of surpassing some obstacles, since the text indicates that Jesus literally can see the inner spiritual sphere of the soul of the unnamed men. Applying the notion of the spiritual senses of Origen and the composition of the place according to Ignatius, the reader can perceive in Mark's narrative that Jesus' seeing is unfailing meta-physical, distinguishing itself from any kind of human visual perception in the episode.

The passage of Mark 5:31-32 puts in evidence the contrast between Jesus' seeing and his disciples' visual perception. The markan author frames the passage in the healing context of a woman with hemorrhages (Mark 5:25-34) which is a narrative inserted or intercalated in the story regarding the raising of Jairus' daughter (5:21-24.35-43). This literary device, also known as a markan sandwich, is not unfamiliar to the markan style, as one can see in 3:20-35; 11:12-25; 14:53-72 ${ }^{38}$.

The context depicts a woman who had been suffering from continual hemorrhages. This unnamed lady knew the Lord was passing by and took her chances to touch at least a piece of his cloak. When she did, Jesus realized what had happened, and then asking to his disciples

36 Cf. M. Zerwick, Biblical Greek (Roma 2001) n. 268; M. Guerra-Gómez, El idioma..., 298.

37 Clement of Alexandria, "Christ the Educator 1.4.» in Ante-Nicene Fathers (eds. A. Roberts, J. Donaldson, A. C. Coxe; Peabody, MA 1994) II, 2.

38 Cf. R. T. France, «The Gospel of Mark...», 234-235. 
"who touched him» $(5: 30)$, they did not understand because the crowd was pressing on him. The disciples employed the verb blépo in present indicative to describe their perception of the event: "You see (blépeis) the multitude pressing in on you». The disciples' notion of an external (physical) seeing is manifested with this statement. They are not yet capable of going further than what is apparent or evident, being also an indicator of a progressive misunderstanding ${ }^{39}$. A sharp contrast is provided by the markan narrative in the emphatic verbal construction employed to portray Jesus' seeing of the same reality: in 5:32 Jesus' seeing is indicated with two verbs of visual perception, one is the conjugated verb periblépo in indicative imperfect, which connotes a durative action that is taking place, meaning that his vision is in progress, not being concluded: «he was looking around $»^{40}$. In regards to this translation, there is a discrepancy between the Greek text of Nestle-Aland and the lectiones of KJV, NAB, NAS ${ }^{41}$ among others that present: "he looked around». The English renditions indicate an aorist indicative, when the Greek text presents an imperfect indicative. In tandem the second verb is the infinitive aorist active of horáō: idein which points toward the finality. It has the aspect of a definitive and punctual action that implies the semantic connotation of individualizing somebody by an intensive visual observation ${ }^{42}$. Consequently Jesus' seeing is hardly a superficial gaze to the crowd, as the one done by the disciples, but it is a selective and personal seeing that wants to identify the concrete person with her whole existential complexity. The seeing of the Lord is effective because it provokes a succession of events that starts with the self-identification of the woman that ultimately will produce a total spiritual healing that gives birth to the faith in Jesus as the Messiah and Son of God.

The scene of the poor and generous widow in Mark 12:41-44, has the narrative function of portraying an incisive dissimilarity with the self-promoted scribes who are heavily criticized by Jesus in Mark 12:38-

39 Cf. M. J. Lagrange, Évangile selon St. Marc (Paris 1966) 141.

40 Cf. M. Zerwick, Biblical Greek, n. 241; V. Scipa, «Stile e spunti di teologia in Mc 5,21-43", Asprenas 30 (1983) 224.

41 KJV: King James Version (1611, 1769); NAB: New American Bible (1970, 1986, 1991, 2010); NAS: New American Standard Bible (1977).

42 Cf. J. Mateos, F. Cамасно, Il Vangelo di Marco. Analisi linguistica e commento esegetico (Assisi 1997) I, 457. 
40. This episode is worth mentioning to the present topic because it shows one of the two occurrences of the verb theorréo having Jesus as its subject. The other instance is Mark 5:38, where is narrated the raising of Jairus' daughter. The pericope states that on arriving to the official's house, Jesus observes/contemplates (theorei) the commotion of the people. His contemplation goes through the real funeral laments, proof of the fatality of death, to perceive that death is not the end, but the opportunity for a new gift of life that comes from God ${ }^{43}$.

Talking about the poor widow's episode, Mark sets it in the second Temple which its entire enclosure had eight gates: two on the South, four on the West, one on the North, and one on the East. The enclosed space was divided into several courts. The largest one was the court of the Gentiles, where everyone could have access to; it was separated from the other spaces by a balustrade prohibiting the Gentiles to pass to the other courts. Subsequently, follows the court of the women that was five steps above the court of the Gentiles; the women could not pass beyond this area. The next court was of Israel, or court of the men, followed by the court of the priests, and then the Holy of Holies or Sanctus Sanctorum ${ }^{44}$. Jesus was sitting down in the court of the women, against one of the thirteen treasury boxes (gazophylákion), contemplating (etheorrei) everyone giving their offering. It is crucial to highlight the tense of the verb theorréo that is in the imperfect indicative form: etheörei. The verbal aspect indicates an action in progress in the past that is not finalized yet or completed ${ }^{45}$, so "Jesus was contemplating». In this case it would not be appropriate to translate «he beheld» (ASV, DRA, ETH, GNV, KJV) ${ }^{46}$, or "he observed» (NAB, NJB, ESV, CJB) ${ }^{47}$, given that would be the proper rendering of an aorist. However, the Greek text is clearly an imperfect indicative signifying an action in progress as it is

43 Cf. R. Pesch, Il vangelo di Marco: Parte prima. Testo greco e traduzione (Brescia 1980) I, 486-487.

44 Cf. J. McKenzie, «Temple», Dictionnaire de la Bible, 875-876.

45 Cf. Wallace: 541.543; Blass-Debrunner: n. 325. 327.

46 ASV: American Standard Version (1901); DRA: Douay-Rheims 1899 American Edition; ETH: Etheridge translation of the NT Peshitta (1849); GNV: Geneva Bible (1599); KJV: King James Version (1611, 1769).

47 NAB: New American Bible (1970, 1986, 1991, 2010); NJB: New Jerusalem Bible (1985); ESV: English Standard Version (2001,2007,2011); CJB: Complete Jewish Bible (1998). 
also showed in the Vulgata: «sedens Iesus contra gazofilacium aspiciebat (was seeing) quomodo turba iactaret aes in gazofilacium» (12:41).

What does Jesus see? The object of the visual perception is the manner ( $p \bar{s}$ / quomodo): how the people were depositing their offering. According to the Mishnah Shekalim 6:5 there were in the temple "thirteen chests» in the form of trumpets upon which were inscriptions specifying the purpose of the offering. The treasury box or gazophylákion refers to the receptacle in the Court of Women used to collect freewill offerings as it is attested by Flavius Josephus in Jewish War 5.5.2 (5.200); 6.5.2 (6.282). Jesus contemplates according to the eyes of God, divine capability that allows him to perceive not the quantity of money but what is hidden beneath the offering made. Jesus was truly recognizing the sacrifice hidden beneath the two lepta or small copper coins, which were the smallest and least valuable coins in circulation in Palestine, worth one-half of a "quadrans» (in Greek Kodrantēs), or 1/128 of a «denarius», which would be a day's salary for a common laborer ${ }^{48}$. The meta-physical seeing of Jesus is confirmed in the instructions imparted to his disciples in vv.43-44, when using an emphatic "amen», Jesus assures that the underprivileged widow put in more than all the other contributors to the treasury. The reason for such affirmation is based upon the spiritual and personal observation of the widow who put in everything that she had, meaning her entire wealth and way of living. The total self-giving to God cannot be unperceived by the one who sees everything. The Lord continues to see what is lacking in those that apparently give much more money from what abounded to them, and what is rich in the heart of a poor nameless widow.

As a précis of the markan characteristics of Jesus' seeing the following considerations can be highlighted:

The initiative comes from Jesus, especially in the pericope of sequela. Jesus' seeing is the first step of the vocation, becoming the primary step of selection that motivates the action of calling ${ }^{49}$. This phenomenon becomes an uncommon practice within the Semitic culture, since it was the disciple who aspires to be accepted by a particular Rabbi or rabbinic

48 Cf. R. Schnackenburg, Vangelo secondo Marco (Roma 2002) 335-336; J. Donahue, D. Harrington, Mark, 364-365.

49 Cf. J. Marcus, Mark 1-8 (Ancor Bible 27A; New York 2000) 183. 
school of the time. The summoning of the disciples turns out to be an original and creative manner of Jesus which creates some kind of discontinuity with the culture of his time ${ }^{50}$. At this point it is convenient to allude to K. Barth who making a paraphrase of the famous Descartian expression "Cogito ergo sum» affirms "Cogitor ergo sum», meaning that in the moment that «I» am thought or perceived by God, in that instant I exist, I am. The initiative belongs to the divinity who always wants to reach out to a person out of love and kindness ${ }^{51}$.

Jesus' seeing is intuitive and personal. He sees the totality of a person scrutinizing every aspect of the spiritual essence. The direct objects of Jesus' seeing are: the divine reality, the faith, the interior of a person and his/her spiritual state. His sight captures everything that would be hidden to a simple human eye. His seeing goes beyond the physical limitations, penetrating the earthly masks, seeing the spiritual or supernatural dimension. This also highlights that His seeing is not casual. It has authority and purpose in the dynamic behavior of Jesus: it becomes the preamble that initiates a calling, act of mercy, teaching, miracle, exorcism or healing. Therefore his seeing is effective, this means that the action that follows immediately after his special perception is already contained in his seeing, e.g., the passages of vocation: Mark $1: 16-20 ; 2: 14^{52}$. Thus, the reader can conclude that Jesus' seeing in Mark turns out to be more than human, since it corresponds to the supernatural seeing of God.

\section{The seeing of the Demons}

The New Testament does present demons as being real (Matt 4,1.17; 8,29; 12,43; Mark 1,34; Luke 4,33-36; 8,31; John 12,31; 13,2.31; 14,17). They are the entities who oppose the action of God, being the contrasting forces that want to destroy the economy of salvation. The demons influence and manipulate the body and soul of a person (demoniac), inflicting a variety of physical manifestations that can be per-

50 Cf. K. H. Rengstorf, « $\mu \alpha \theta \eta \tau \eta \dot{s », ~ e n ~ G . ~ K i t t e l ~(d i r .), ~ T h e o g i c a l ~ D i c t i o n a r y ~ o f ~ t h e ~}$ New Testament (Eerdmans, Grand Rapids 1970) IV, 446-447; M. Hengel, The Charismatic Leader and His Followers (trans. J. Greig; Edinburgh 1981) 50-51; J. R. EDWards, The Gospel according to Mark (Grand Rapids 2002) 49.

51 Cf. J. Palachuvattil, «He saw», ... 101. n. 19.

52 Cf. J. Palachuvattil, «He saw», ... 102; J. R. Edwards, Mark, 49-50.81-82. 
ceived as illness or infirmities in the Semitic mindset like dumbness (Matt 9:32), blindness (Matt 12:22), epilepsy (Mark 9:17-27), and insanity (Mark 5:1-5); on the other hand, a close reading of Mark's Gospel helps to identify the differentiation of a demoniac from those who are afflicted with ordinary bodily maladies, i.e., Mark 1:32 16:17.18 ${ }^{53}$.

In Mark's narrative, it is crucial to draw attention to three important passages that can summarize the constant pattern of behavior of the demons, specially to determine the manner of their "seeing» in the context of demoniac possessions and exorcisms: Mark 3:11-12; 5:6-7; 9:20.

The text of Mark 3:11-12 exhibits a noteworthy markan summary that concentrates a prolonged period of time in two verses where the characters, namely "the unclean spirits» (tá pneúmata tá akárthata), meaning the people who they possess and through whom they speak, were beholding/contemplating (etheóroun) Jesus repeatedly in different occasions. The use of the verb theorré in imperfect indicative third person plural: etheóroun indicates a regularly recurring activity in past time that can be classified as habitual ${ }^{54}$. Taking in consideration this verbal aspect, most of the English versions translate the verb as it would be an aorist: "beheld" and «saw» accompanied with the adverb of time "whenever» or "when", to express the habitual character of the imperfect. Therefore the summary passage contained a pattern of behavior that can be described as a spiritual perception which is typical of supernatural beings. Thus such a way of seeing subsists implicitly in every encounter of a demoniac with Jesus narrated in Mark's Gospel.

A parallel reading of the three texts mentioned above makes possible to the reader to determine the following pattern of conduct of the unclean spirits:

The first one to see is the unclean spirit. Mark makes explicit in his narrative that the first perception comes from the demoniac: $3: 11 ; 5: 6$ and 9:20. They are the subject of the verb that communicates a habitual action $(3: 11)$ or a vision in progress expressed in participle $(5: 6 ; 9: 20)$.

53 Cf. W. Foerster, «doí $\mu \omega v »$, en G. Kittel (dir.), Theogical Dictionary of the New Testament (Eerdmans, Grand Rapids 1970) II, 18-19; G. E. Sterling, "Jesus as Exorcist: An Analysis of Matthew 17:14-20; Mark 9:14-29; Luke 9:37-43a», The Catholic Biblical Qarterly 55 (1993) 477; J. R. Edwards, Mark, 277-278.

54 Cf. D. Wallace, Greek Grammar beyond the Basis. An exegetical Syntax of the New Testament (Grand Rapids 1996) 548; Blass-Debrunner, n. 325. 327. 
The direct object of their vision is Jesus. They identify him immediately, and in doing so, their reaction is described vividly by the evangelist: «they would fall down (prosépipton) before him and cry out» (Mark 3:11). The verb employed is prospiptō in imperfect tense (prosépipton) denoting a repeated or habitual action of submission rather than an act of worship or homage ${ }^{55}$. In the episode of Mark 5:6 the verb used is proskunéo which indicates a physical reaction of reverence and respect to a higher power ${ }^{56}$. These passages connote, therefore, the image of the prostration before a superior authority as it can be seen in other texts as Gen 17:3; Dan 3:5; Matt 2:11; 4:9. Mark's author, speaking of the agency of the demon rather than of the victim, states that they never run away from the presence of Jesus, becoming an outstanding characteristic in the narrative, because it would be easier to think of a demon that flees from the perturbing and dominant presence of Jesus rather than remaining and humbling themselves. But the Gospel is clear in this aspect, they stay and prostrate, indicating that there is no escape from the presence of God and his absolute power capable of overcoming them ${ }^{57}$.

The demons usually have the capacity to speak in their own persons (Mark 1:23-24; 5:7; also see Matt 8:29), however, when they face down before Jesus, their deed is complemented with a profession of faith that reveals the true nature of their seeing: "you are the Son of God» (Mark 3:11) or "Jesus, Son of the Most High God" (Mark 5:7; also 1:24). This ultimate truth about Jesus reveals a high Christological confession, already announced by God in Mark 1:11; 9:7 and now put in the lips of a supernatural entity, but hidden from everybody else in general ${ }^{58}$. Such statement demonstrates that they can also observe behind the different layers of human appearances, being able to see without difficulty what others could not see: his divine nature. As representatives of a supernatural dimension, the demons possess a knowledge and visual perception superior to that of the disciples, followers or any other

55 Cf. E. Gould, Critical and Exegetical Commentary on the Gospel according to St. Mark (Edinburg 1961) 56; M. E. Boring, Mark. A Commentary (Louisville London 2006) 98-99.

56 Cf. B. van Iersel, Mark. A reader-response Commentary (London, UK/New York, NY 1998) 198.

57 Cf. J. Marcus, Mark 1-8, 259.

58 Cf. R. T. France, «The Gospel of Mark...», 155. 
human in Mark's narrative. Therefore there is a profound irony in the gospel narratives when the reader notices that the ones who Jesus came to combat are the first ones to recognize Him for what he truly is. On the other hand, the scribes are the one who affirm that Jesus is possessed by Beelzebub, and by the prince of demons He is driving out demons (Mark 3:22). Consequently, the demonic confession of the Christological identity exhibits a simple proclamation of the truth of His eschatological lordship which does not imply an embrace of faith, love, and trust in Jesus ${ }^{59}$.

Distinctive of their behavior are the violent reactions, indicators of the overwhelming power emanated from Jesus that torments the unclean spirits. The acknowledgment of Jesus' divine nature is expressed with a loud scream (krazein) in Mark 5:7, heightening the drama of pain which is an echo of the exorcisms of the demoniac of Capernaum (see Mark 1:21-28). The evil entities in order to channel their distress and pain produced by the presence of God, inflict pain and suffering to their victim, as it is the case of Mark 9:20, where the wordless reaction of the demon expresses its response to Jesus: «the spirit immediately tore him (synespárazen); and falling upon the earth he rolled foaming». The verb sysparásso evokes the image of a dog tearing up a carcass that in this text is used analogically to indicate a convulsion ${ }^{60}$. The violent reactions continued while Jesus is present until the moment of his command of leaving the boy in v. 26 .

At the end of every encounter of the unclean spirits with Jesus the outcome results to be a liberating experience, a restoration of the wholeness that was lost because of the evil presence, which evidences the supremacy of the power of Jesus over the demoniac forces, e.g., Mark 9:26-27. This dominance can be seen overtly in the permission asked by the demons to go into the pigs in Mark 5:12, which was granted by Jesus (5:13) causing the deliverance of the man who had been possessed, restoring his natural condition of being a social person capable of having a harmonious life again (5:14-16).

59 Cf. B. Witherington III, The Gospel of Mark (Grand Rapids - Cambridge, UK 2001) 144; J. Marcus, Mark 1-8, 259.

60 Cf. R. T. France, «The Gospel of Mark...», 366. 
As a consequence of what was explained, it can be concluded that the demons' seeing can be regarded as meta-physical since they are considered spiritual entities who perceive what is proper of the supernatural realm, and therefore one can be in agreement with the words of Athanasius in his work entitled On the Incarnation of the Word 32.4: "the spirits especially see through what is unseen by human eyes ${ }^{61}$.

\section{Conclusions}

The episodes of visual perception treated previously exhibit different semantic levels of comprehension connected with the aspect of seeing. The demons, for example, who are the characters that function in the narrative as the antagonist of the hero, present a spiritual seeing capable of perceiving the divine manifestation hidden under the human condition; in the same way Jesus sees with the eyes of God catching sight of what is hidden to the human eye, but the outcome and the effects of their seeing are radically opposed. The spiritual seeing of these personages, therefore, manifest diverse semantic levels that are incorporated in contexts of exorcisms, healing, divine manifestation of God, vocation, instruction, etc. For this reason, as manner of a conclusion, it is possible to highlight five lines of semantic dimension in which the action of the «spiritual seeing» remains intrinsically related to different fields of understanding of the text.

a) The seeing in the Christological dimension: the passages manifest an essential relationship between the «seeing» and Jesus' identity. Right from the beginning of Mark's Gospel the double celestial object of Jesus' vision and the hearing of the divine voice of God the Father established the pattern of the divine sonship of Jesus, a Trinitarian dimension that qualifies his Christological identity (Mark 1:10-11) ${ }^{62}$. The encounter with the demoniacs continue the same line of theological thought, manifested in the demons' voice as part of their characteristic reaction which starts always with a "seeing» that leads to the acknowledgement of the superior power of God. Their proclamation expresses the truth about Jesus that begins with the spiritual visual perception. But their oral manifestation is not totally equivalent to the divine voice of the

61 T. C. Oden, C. A. Hall, eds., Mark. Ancient Christian Commentary on Scripture II (Downers Grove 1998) 64.

62 Cf. J. Palachuvattil, «He saw», ... 263-264. 
Father in 1:11, because the demoniac reacts out of fear, expressing only the objective divine truth about the Son of God in Jesus, while the voice of the Father is expressed out of love.

b) The seeing and a dialogic movement of relationship: the dynamic expressed with the act of seeing can be described as a dialogue in which the one who sees first, having the initiative, provokes a reaction from the one who is seen. In this manner the interaction becomes dynamic, producing effective results that have a positive outcome, thanks to the presence of Jesus who functions as the source of power and goodness ${ }^{63}$. In the cases where the initiative belongs to Jesus, the reader recognizes that his seeing implies a personal connection with his interlocutors that provokes a reaction manifested in distinct forms of responses (positive and negative) through the calling to experience a sequela Christi.

In the episodes of exorcism, the initiative of the seeing belongs to the demons, who are the first ones to recognize the divine presence of the Son of God in the human appearance of Jesus. The double interrelational movement starts with the demons, who always provoke a reaction in Jesus that ends up with the complete healing and restoration of the possessed person. The dynamic of the encounter narrated according to the human level manifests the divine reality hidden in the human appearances. The episodes described in Mark 3:11-12; 5:6-7; 9:20 display a clash of the two basic forces: good and evil, which at the same time transport the reader to an eschatological level that incarnates the eternal battle of the universal cosmic forces where always the power of God and of Jesus prevails against the evil forces that pursue the destruction of harmony and balance in the human state ${ }^{64}$.

c) The seeing and the healing dimension of the human condition: the previous semantic dimension leads us to the fact that Jesus' seeing promotes a chain reaction manifested in the unfolding of the events that conclude with the total renovation and healing of the possessed. The demons destroy the harmonious balance of living and communication that a person had during the pre-possessed state, to the point of isolating him or her from other persons and from God himself. Thus the context of exorcism becomes at the same time episodes of

63 Cf. M. E. Boring, Mark, 274.

64 Cf. R. T. France, «The Gospel of Mark... „ 366-367. 
healing since they describe the re-establishment of the ideal state of communication and functionality in the social community and with the personal God of Jesus. Other episodes of healing are the ones characterized by the absence of demons: the paralytic man in Mark 2:1-5 and the anonymous woman with hemorrhages in Mark 5:3132. In both cases the process of healing also begins with Jesus' seeing which implies more than just a physical perception of the reality in front of him.

d) Jesus' seeing and a didactic dimension: the pedagogical aspect of Jesus' seeing is manifested explicitly in the episode of the poor widow in Mark 12:41-44. The narrative does not describe a context of exorcism or healing. Jesus simply observes «how» the people were putting their offering. His persistent and spiritual contemplation of the human condition motivates him to impart an instruction to his closest friends, the disciples $\left(12: 43^{\mathrm{a}}\right)$. The purpose of the didactic communication described in a direct style discourse of $12: 43^{\mathrm{b}}-44$, is to educate the disciples to "see» as God «sees», this means to grow in the capacity to perceive the reality with the spiritual eyes in order to discover what is hidden to the human sight, because man looks to the outward appearance of every situation, but Jesus, which is the evident proof of God's seeing, perceives the soul and heart. This attitude of Jesus echoes the instruction of Yhwh to Samuel during the moment of choosing David, when the Lord said to Samuel, «do not look at his appearance or at the height of his stature, because I have rejected him; for God sees not as man sees, for man looks at the outward appearance, but the Lord looks at the heart» (1Sam 16:7).

e) Pragmatic dimension of the texts: the pericopes studied under the perspective of the spiritual senses manifested in the writings of Origen, Bonaventure and Ignatius of Loyola, lead us to read Mark's Gospel from a pragmatic approach, which is an extension of the semantic analysis of the episodes. The pragmatic reading leads us to the point of the purpose of the text, this means, for what were these narrations written for? What is the importance for the modern reader? What do the episodes ask the reader to do? ${ }^{65}$

65 Cf. B. Schlieben-Lange, Linguistische Pragamatik (UTB 198; Stuttgart 1979) 97. 
The Gospel narratives were written to inform about the truth of the event of Christ, so they have a fundamental informative dimension, but also the written kerygma has the purpose to persuade the reader to act and believe in what is recounted, so it has also a practical aspect that motivates to act upon what is communicated. These particular Gospel episodes must be considered, consequently, under the content and the finality that implies an active participation of the readers, independently of the place and time in which they can be situated ${ }^{66}$. Therefore the episodes that described Jesus' seeing have a "directive function» which is also called a "conative». Such narrative dimension motivates the reader to act by way of imitation and identification with the character of the narration ${ }^{67}$. The pericopes present to the reader a pragmatic way to follow and practice, in daily life, the spiritual seeing that is portrayed in Jesus. In this line of thought, the author of Mark makes explicit this intention with the didactic instruction of Jesus to his disciples, regarding the situation of the poor widow (12:41-44). He makes the emphasis in the event so the disciples will learn how to perceive the human reality according to the mindset of God. In the same manner, the author wants to transmit this way of seeing to his markan community, which incorporates every Christian community through the path of time that reads and meditates the kerygmatic episodes of visual perception. At this moment, it is quite useful the application of the criteria established by Origen that found echo in the thoughts of Bonaventure and Ignatius of Loyola. Through the practice of the spiritual senses, especially the spiritual sense of sight, a person can obtain experiences of the divine immersed and hidden in the human condition.

66 Cf. W. EgGer, Lecturas del Nuevo Testamento (Estella 1990) 162-163.

67 Cf. R. LACK, Letture strutturaliste dell'Antico Testamento (Roma 1978) 25-28; W. EgGer, Lecturas, 169-170. 
Abstract: In Mark's narrative, it is possible to identify three important verbs that signify visual perception: Horáō, Blépō, and Theōréō with their respective nuances. In addition to their lexicographic definitions, they acquire a very unique semantic dimension depending on their subject, object, and narrative context. These syntactic and narrative determinations of the analysis applied to selected texts allow the reader to discover a meta-physical portrait of seeing in Jesus and the demons. This means that their seeing goes beyond the physical limits of the corporeal perception, being able to perceive the supernatural dimension immersed in the circumstantial events. This reading founds its hermeneutic ground in the notion of the soul' senses developed by Origen which found later on its development in the theological thoughts of Bonaventure, and its practical and spiritual application in Ignatius of Loyola's spiritual exercise. This hermeneutic key applied to the Markan pericopes through the narrative and semantic approach helps the reader to discover the spiritual dimension of the perception of Jesus and the demons, and their semantic implications in the kerygmatic narrative addressed to the community implied as the receptor of the markan message.

Keywords: Horáó, Blépō, Theōréō, to see, to observe, to contemplate, Jesus, Demons, physical, meta-physical.

Resumen: En la narrativa del evangelio de Marcos es posible identificar tres verbos fundamentales que significan percepción visual: Horáō, Blépō y Theōréō. Estos engloban diversos niveles de significación que necesitan la ayuda del léxico especializado; pero esto no es suficiente para establecer otras dimensiones semánticas que se adquieren dependiendo del sujeto, objeto y contextos en los cuales los vocablos son empleados. El lector puede descubrir a través del uso del vocabulario y del método semántico-narrativo la dimensión del «ver» espiritual como uno de los sentidos del alma especialmente caracterizado en el evangelio de Marcos. Este tipo de lectura ya encuentra su fundamento hermenéutico en los escritos de Orígenes que tratan sobre los sentidos espirituales del alma que permiten la percepción de la acción divina escondida en la humanidad contingente. Tal noción es desarrollada de manera más sistemática en las reflexiones teológicas de Buenaventura, que luego se manifestarán en manera práctica a nivel espiritual en Ignacio de Loyola. Este fundamento hermenéutico puede ser aplicado a los episodios de Marcos, ayudando al lector a percibir que los retratos narrativos del «ver» de Jesús y los demonios adquiere una dimensión metafísica, ya que ellos perciben la realidad divina-espiritual escondida en la apariencia circunstancial que escapa a la visión física.

Palabras clave: Horáó, Blépō, Theōréō, ver, observar, contemplar, Jesús, demonios, físico, metafísico. 
